\title{
水銀耐性遺伝子の水銀浄化への利用
}

\author{
芳生秀光
}

\section{Application of Mercury-resistant Genes in Bioremediation of Mercurials in Environments}

\author{
Hidemitsu PAN-HOU \\ Faculty of Pharmaceutical Sciences, Setsunan University, 45-1 Nagaotogecho, \\ Hirakata, Osaka 573-0101, Japan
}

(Received May 1, 2010)

\begin{abstract}
Mercury and its organic compounds, especially methylmercury are extremely hazardous pollutants that have been released into the environment in substantial quantities by natural events and anthropogenic activities. Due to the acute toxicity of these contaminants, there is an urgent need to develop an effective and affordable technology to remove them from the environments. Recently, attempts have been made to utilize bacterial mer operon-mediated reduction and volatilization of mercurials for environmental remediation of mercury pollution. However, application of this technology to the treatment of mercury-contaminated environments has been limited by social concerns about the release of volatile mercury that will become part of the local mercury cycle and repollute the environment again, into the ambient air. To improve this environmental problem, a new mercury scavenging mechanism that could be expressed in living cells and accumulates mercury from contaminated site without releasing mercury vapor is necessitated. To construct a new biocatalyst that is capable of specifically accumulating mercury from contaminated sites without releasing mercury vapor, we have genetically engineered bacteria and tobacco plant for removal of mercury from wastewater and soils, respectively, to express a mercury transport system and organomercurial lyase enzyme simultaneously, and overexpress polyphosphate, a chelator of divalent metals. The applicability of these new engineered biocatalysts in the environmental remediation of mercurials is evaluated and discussed in this review.
\end{abstract}

Key words—— mercury pollution; polyphosphate kinase gene $(p p k)$; $\operatorname{mer} T$; $\operatorname{mer} B$; transgenic tobacco; bioremediation

\section{1. はじめに}

水銀及びその化合物は，極めて有用な化学的，物 理的性質を持つため，古くから人類によって様々な 形（化学触媒, 防腐剂, 抗スピロヘータ剤や農薬な ど）で利用されてきた. 社会の近代化に伴い水銀の 産業用途は拡大し，多量の水銀化合物が使用される ようになったが，現在では当然のことである環境污 染や健康障害に及ぼす影響には長い間注意が払われ ず，今なお解決すべき大きな社会的課題として残さ れている.

1932 年から 1971 年までの間にアセトアルデヒト 製造工場から水俣湾周辺に投棄した水銀量はおよそ

摂南大学薬学部（干573-0101 枚方市長尾峠町 45-1) 現住所：=299-0261 千葉県袖ヶ浦市福王台 1-2-4 e-mail: hm-md-hou@tj8.so-net.ne.jp 本総説は, 平成 21 年度退職にあたり, 在職中の業績を 中心に記述されたものである。
80 トンに及んだと推定されている. ${ }^{1-3)}$ その結果, あの悲惨な水俣病を引き起こし，数十年間周辺地域 の住民に多大な苦痛を与えたことは記憶に新しい. また, 戦後間もない1953 年頃に, 食糧増産の至上 命題のもとでイネのイモチ病やムギのサビ病などの 予防を目的として酢酸フェニル水銀農薬の使用が認 められてから，水銀農薬の使用量は飛躍的に増加し た. 1968 年にその使用が中止されるまでの 16 年 間，約 2300 トンの酢酸フェニル水銀農薬が狭い国

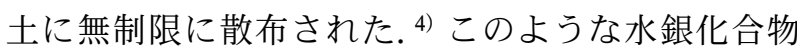
による環境污染は国内のみならず国外でも大きな社 会問題となっている. 中国貴州省貴陽市で 1971 年 から 2000 年までの約 30 年の間に約 130 トンに及ぶ 水銀化合物が投棄された. ${ }^{5)}$ 中国以外にもブラジ ル，ロシア，タンザニアや東南アジア地区などでは 金の採掘・工場排水等による高濃度の水銀化合物に よる環境污染が依然として進行しており，わが国の 
悲劇が繰り返されようとしている。

以上のように国内外を問わず，水銀農薬の濫用あ るいは化学工業で使われた水銀化合物の廃棄，漏出 により土壌，河川などの生活環境が污染された地区 は多数存在する．水俣湾内で高濃度の水銀により污 染されたへドロは，その後埋め立てという非常に多 額の費用を要する物理的処理により一応の収束をみ ているが，埋め立てられた地区からの水銀流出が懸 念され，完全に終結したとは言い難い.

水銀化合物は極微量で強い生理作用を示すため, 現在，その使用と廃棄に対しては厳しく規制されて いる，そのため，特定の場所で大量に水銀が使用・ 廃棄されるということはほとんどない。しかし，近 年の IT 革命や化石燃料の消費や医療行為などの日 常生活に欠かせない人間の社会活動により，個々の 製品や機器において使用されている水銀化合物は微 量ではあるが，総量としては無視できない水銀化合 物が持続的に環境に排出され続けている．現在，わ が国や先進国における水銀化合物の污染問題は，既 に水俣地区等で代表されるような高濃度で局所的な 污染の段階から，微量ではあるが長期間にわたり污 染されることによる人体への影響が問題とされる段 階へと進んできている．微量水銀の除去方法にはい ろいろな試みがなされているが，目下のところ有効 な方法は開発されていない。現状では，生活環境に 蓄積された水銀化合物の量は少しずつ増加し，低濃 度ながらもその污染が広範囲に及んでいる。このよ うな状態をそのまま放置すると，水銀化合物による 環境污染はさらに拡大することは容易に予測され る。その結果，水俣や新潟において日本人のみが経 験した，長く辛い苦しみを世界各地で再び経験する のではないかと危惧される．環境に放出される水銀 化合物の安全かつ有効な浄化法の開発は全世界的な 要望である，筆者は，微量の水銀化合物による污染 環境の修復ができ，かつ環境に優しく，安全・安価 な水銀浄化・回収法の開発を目指して研究を続けて きた。

本稿では，まず，Pseudomonas K-62 の水銀耐性 遺伝子の解析結果について簡単に紹介する。次に, 本菌株の持つ水銀耐性遺伝子を利用した水銀化合物 の浄化技術の開発について筆者がこれまで行つた研 究及びその成果を中心に紹介する.

\section{Pseudomonas K-62 の水銀耐性遺伝子の解析}

水銀化合物は生体成分，特にタンパク質の SH 基 に強い親和性を持つために微生物に対して強い殺菌 作用を示す。水俣湾などのある特定の環境において は，水銀濃度がしばしば微生物を死に至らしめるレ ベルまで増加することがある。しかし，その環境に は水銀化合物の毒性に耐え抜いた水銀耐性微生物が 存在している。これらの微生物は水銀化合物に対し てどういう機序で水銀而性を獲得しているのだろう か.この問題についてはこの三十数年の間にほぼ解 明されてきた。現在，微生物の水銀耐性獲得機序と しては，1）水銀化合物の菌体内への取り込夕の減 少による而性獲得, ${ }^{6}$ ) 2) 微生物から産生した硫化水 素と水銀化合物との反応，すなわち，不溶性の硫化 水銀化合物への変換反応による耐性獲得, ${ }^{7)} 3$ ) 菌体 内での水銀化合物のメチル化反応による耐性獲 得, ${ }^{8-10)}$ 4) 菌体内での水銀化合物の還元・気化反応 による耐性獲得11-15)の 4 つがよく知られている。こ のうちの 1)-3）の耐性機構は極めて限られた微生 物にのみみられる現象である。一方，これに対して 4）の場合は好気性細菌など，ごく一般的な微生物 にみられる水銀耐性獲得機序である.

Pseudomonas K-62 は，外村らにより酢酸フェニ 儿水銀で濃厚に污染された土壌から単離された水銀 耐性菌である. ${ }^{15,16)}$ 本菌株は無機水銀のみならず, メチル水銀を始めとする他種類の有機水銀に対して も強い耐性を示し，特に酢酸フェニル水銀に対して 通常の細菌の数千倍の耐性を有している（Table 1)。本菌株の水銀耐性は有機水銀を無機水銀に分解 する有機水銀分解酵素（リアーゼ）及び無機水銀を 金属水銀に還元する水銀還元酵素（レダクターゼ） の 2 つの酵素系の関与により獲得されていることが

Table 1. MIC of Mercurials for Bacteria

\begin{tabular}{lcc}
\hline \hline \multirow{2}{*}{ Bacterial strain } & \multicolumn{2}{c}{ Mercurials $(\mu \mathrm{g} / \mathrm{ml})$} \\
\cline { 2 - 3 } & MC & PMA \\
\hline Pseudomonas K-62 & 450 & 120 \\
Serratia mercescens (pDU1358) & 12 & 6 \\
Escherichia coli (Tn 21) & 35 & 0.2 \\
Escherichia coli & 0.1 & 0.05 \\
Pseudomonas aeruginosa & 0.1 & 0.1 \\
Bacillus subtilis & 0.1 & 0.05
\end{tabular}

MIC; Minimum inhibitory concentration, MC; Mercuric chloride, PMA; Phenylmercuric acetate. 
外村の研究グループにより明らかにされた. ${ }^{17-22)}$

その後 30 数年の間に多種類の水銀耐性菌が次々 に単離され，これらの微生物の水銀耐性機構に係わ る遺伝子の解析が活発に行われるようになつた。 そ の結果，微生物の示す水銀耐性の多くはプラスミド 又はトランスポゾン上に存在する機能の異なる複数 の水銀耐性遺伝子により構成された水銀耐性オペロ ン（mer operon）により支配されていることが明 らかにされた. ${ }^{11-15)}$ mer operon の構造は微生物種 や水銀化合物種に対する耐性の相違によって多少の 違いがある。無機水銀耐性を支配する mer operon は, mer operonの発現を制御する調節遺伝子 merR 及びペリプラズムで水銀との結合に関与する遺伝子 $m e r P$, 水銀の膜透過に関与する輸送遺伝子 $\operatorname{mer} T$, 水銀イオンを金属水銀へ変換する働きを持つ水銀還 元酵素遺伝子 $m e r A$ 及び $m e r$ operon の発現を制御 すると考えられている merD などの遺伝子から構成 される，一方，無機水銀のみならず有機水銀に対し ても耐性を示す微生物は上記の遺伝子構造に加え て，さらに有機水銀から無機水銀への変換反応に関 与する有機水銀分解酵素遺伝子 $\operatorname{mer} B$ を保有してい る. ${ }^{11-14,23-26)}$ この共通した遺伝子のほかに，メチル 水銀及び無機水銀の膜輸送に関与すると考えられて いる $m e r E,{ }^{27-29)}$ 無機水銀の膜輸送に関与すると考 えられている $\operatorname{merC}$, $^{30-32)} \operatorname{merF}{ }^{33,34)}$ 及びペリプラズ ムでフェニル水銀の取り込夕制御に関与すると考え られている $\operatorname{merG}{ }^{35)}$ などの遺伝子は，それぞれ異な る mer operon 上に存在することが次々に確認され
た (Fig. 1).

Pseudomonas K-62 の水銀耐性獲得の生化学的機 序は，いち早く詳細に研究解明されているにもかか わらず，その遺伝学的研究は 1990 年までに全く行 われていなかった。筆者らの研究により本菌株は 6 本のプラスミド $(82,68,56,31,26$ 及び $8.5-\mathrm{kb})$ を 保有しており，そのうちの 26-kb（pMR26）及び 68-kb（pMR68）のプラスミドが本菌株の水銀耐性 に関与していることが判明した（Fig. 2). 27) また, pMR26 上に $\operatorname{merR}$-o/p-merT-merP-mer $A$ - merG merB1-merR-o/p-merB2-merD から構成された有機 水銀化合物の分解を司る 2 組の mer operon が存在 することを明らかにした. ${ }^{24,25)}$ さらに，それらの遺 伝子の機能について調べ, 水銀輸送系遺伝子, $m e r T-m e r P$ は無機水銀の取り込み・輸送のみなら ず，フェニル水銀の取り込み・輸送にも関与してい るが，メチル水銀の取り込み・輸送には関与しない ことを初めて明らかにした. ${ }^{36-38)}$

さらに, pMR26 上にフェニル水銀の分解と還元 反応に関与しないが，フェニル水銀耐性獲得に関与 する新規遺伝子の存在が確認され，筆者らはこの新 規遺伝子を $m e r G$ と名付けた. ${ }^{35)} \operatorname{mer} G$ を欠失した 変異株の水銀化合物の取り込夕活性は， $\operatorname{mer} G$ を保 有する野生株に比べて，無機水銀に対してはほとん ど差異がみられないが，フェニル水銀に対しては著

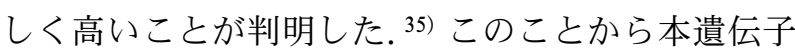
はフェニル水銀の取り込夕抑制に㗢く遺伝子である 可能性が考えられた。その他の遺伝子は既報の遺伝

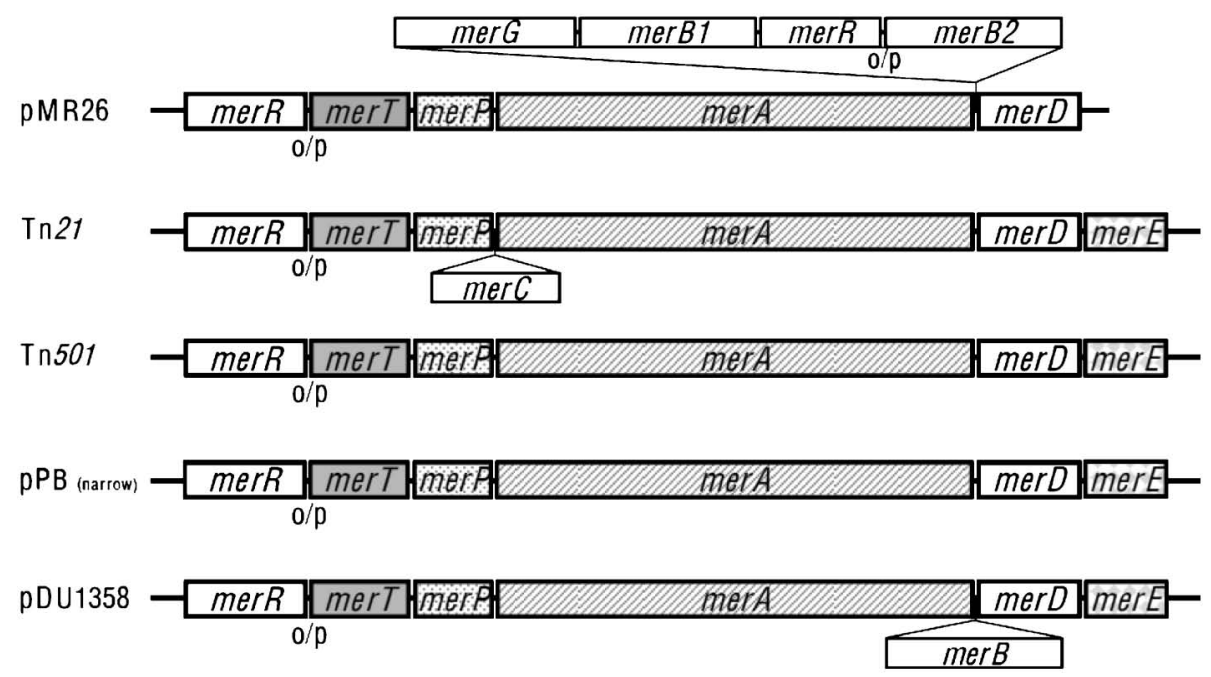

Fig. 1. Schematic Representation of Bacterial mer Operons 


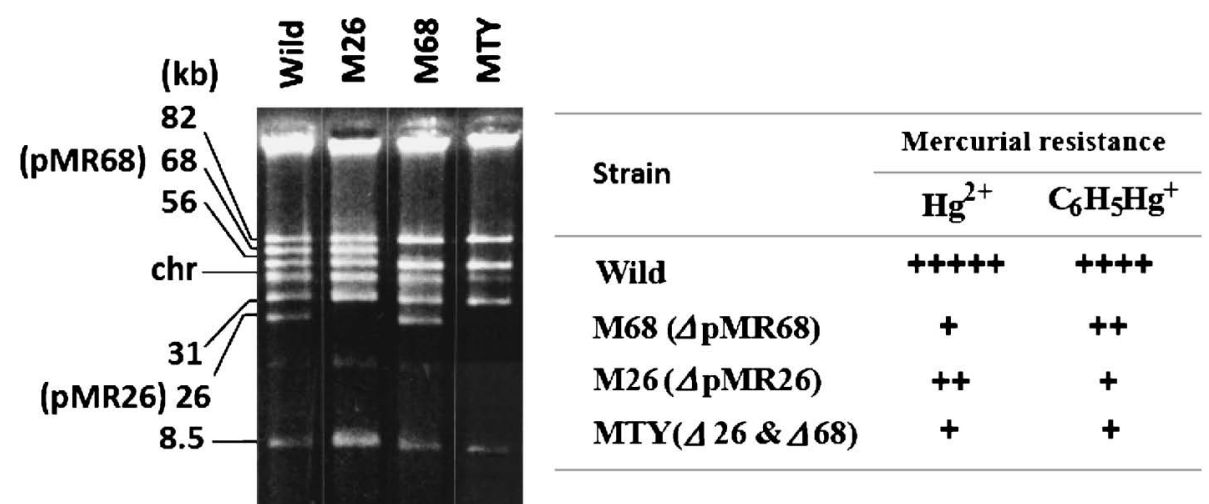

Fig. 2. Mercury Resistance of Plasmid-defective Strain Isolated from Pseudomonas K-62
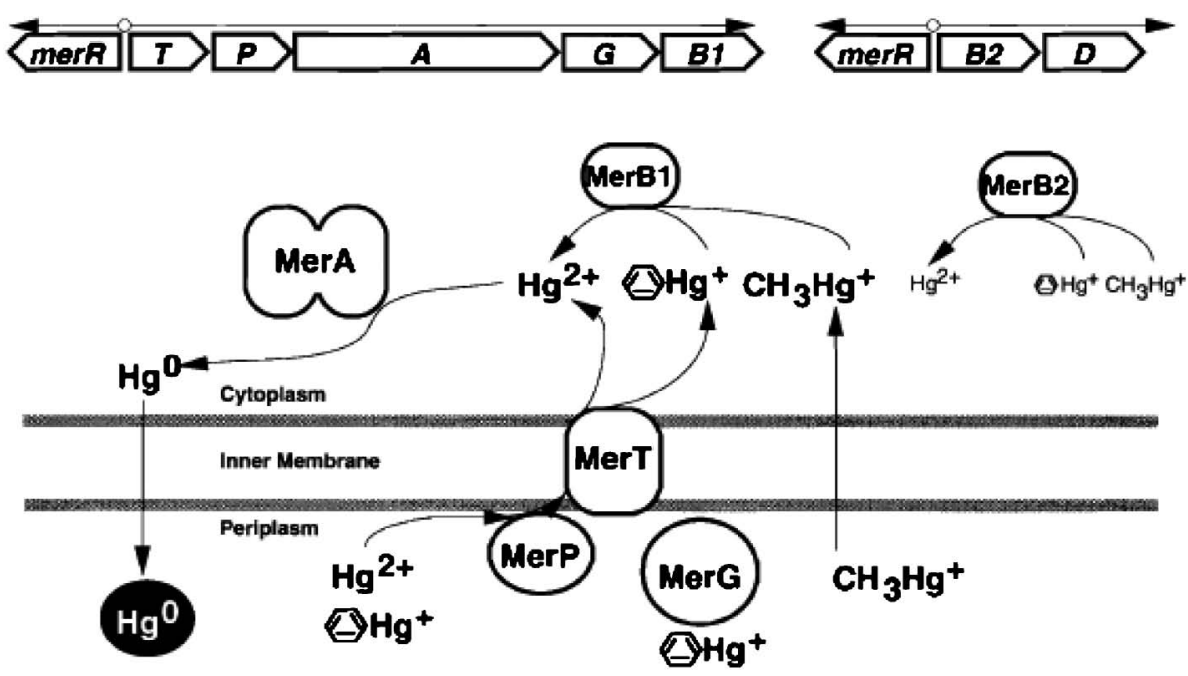

Fig. 3. Mercury Resistance Systems Encoded by Pseudomonas K-62's pMR26

子とほぼ同じ機能を示していることが確認された。

以上のように pMR26 の mer operon 上の水銀耐 性遺伝子の数またその配列順序は, ほかの水銀而性 菌の持つ mer operon の構造と微妙に異なっている こと，また，機能が同じである有機水銀分解醭素を コードする $\operatorname{mer} B$ 遺伝子は複数存在することも明ら かにされた，この mer operonの多様性の理由につ いてはまだ十分に解明されていないが，恐らく微生 物の生存する環境における水銀化合物の曝露の違い によってもたらされた結果ではないかと考えられる。

Pseudomonas K-62 の有機水銀耐性は, 未解析の pMR68 上の水銀耐性遺伝子に加えて pMR26 上の 2 つの有機水銀分解醳素遺伝子 (merB1, merB2) と 1 つのフェニル水銀の取り込久抑制遺伝子 $(m e r G)$ などを有し, 多数の遺伝子の制御によって獲得して いると推測される (Fig. 3).

\section{3. 水銀污染浄化法}

3-1. 物理化学的净化法 現在, 一般に広く利 用されている無機水銀廃水の浄化処理方法は硫化物 凝集沈殿法である. すなわち, 水銀化合物を含む排 水に硫化ナトリウムを添加することにより水銀化合 物を極めて難溶性である硫化水銀として凝集沈殿さ せ回収する方法である。この方法では $\mathrm{pH}$ と $\mathrm{S}^{2-}$ の 濃度が硫化水銀の生成に大きな影響を与える. 水銀 濃度が低い場合は, 硫化水素が過剩に存在し，かつ $\mathrm{pH}$ の上昇に伴って多硫化水銀が生成し, 再溶解が 進むという欠点がある. また, この方法を用いて水 銀化合物を環境基準值以下にまで浄化処理すること は極めて難しい，その上，後処理を必要とする場合 が多い.

硫化物凝集沈殿法のほかには, 活性炭や水銀キ レート樹脂を用いた水銀除去法（活性炭吸着法， イ 
オン交換法）などがある。 $1,39,40)$ 活性炭は一般に界 面活性のある疎水性の大きい物質をよく吸着する性 質を持ち，疎水性の金属水銀を吸着する。そのた め, 蒸気や微粒状の水銀は活性炭に吸着する。ま た，塩化第二水銀や酢酸フェニル水銀もよく吸着で きることが知られている。活性炭による水銀化合物 の除去は, ppm レベル以上の比較的高濃度の水銀 化合物に対して有効であるが，ppbレベルの低濃度 水銀化合物に対する除去効率は極めて悪い。さら に，活性炭は水銀化合物以外の有機化合物も吸着す るので有機物共存系での使用は難しく，また，使用 済みの吸着剂の再生も難しいという欠点がある.

現在最も一般的に用いられている排水に含まれる 水銀化合物の除去法は，強塩基性陰イオン交換樹脂 を用いるイオン交換法である。この場合，水銀は陰 イオン錯体として樹脂に吸着除去されるので，まず 水銀錯アニオンを形成させることが必要となる。こ の錯アニオンを形成し易いのが無機水銀イオンであ り，イオン交換法は無機水銀イオンの除去に強い効 果を発揮する。しかし，水質の環境基準を満足する 程度に水銀除去を行うことはほぼ不可能であり，特 にコロイド状の金属水銀や不溶性硫化水銀の除去に は全く不適である。

以上述べた物理化学的処理法を用いて水銀化合物 を環境基準值以下にまで処理することは困難であ り，加えて各種処理条件の設定や処理能力の問題, また，吸着体の取り替え頻度や大量の処理試薬の投 入といったコスト高の問題，特に，環境中に処理試 薬を大量投入することにより新たな化学物質による 環境污染が発生するという問題があり，污染現場へ の適用は難しい。これらの問題点を回避し，かつ経 済的・効率的な水銀浄化を行うためには，従来の物 理化学的処理法よりも生物活性を利用した生物学的 処理法が適していると考えられる.

3-2. 生物学的浄化法 近年，金属などの化学 物質による環境污染の解決策としてバイオレメディ エーション技術が有効であることが注目されてい る.バイオレメディエーション技術とは，一般に生 物機能を活用して污染された環境を修復する技術で ある，湾岸戦争時に，クウェートの油井から噴出し た原油による生活環境污染が大変深刻な問題となつ たことは記憶に新しい。 その際に流出した原油を微 生物の石油分解能を利用して浄化するという試みが
実際に行われた。この技術は，污染現場への特別な 化学薬品の投入や特殊な反応条件の設定などの必要 がなく，また，手ごろなコストで環境中の污染物質 を環境生物に受容可能なレベルにまで減少させるこ とのできる新しい方法である，本技術は低濃度で広 範囲な水銀污染に対しても有効であると考えられる.

このように, 生物学的浄化法は安全性あるいは経 済的な観点からも極めて魅力的な方法である．水銀 のバイオレメディエーション技術は大きく分けて 2 つに分類される. 1 つは水銀のバイオボラタイゼー ション，もう 1 つは水銀のバイオアキュミュレーシ ヨンに基づく方法である.

3-2-1. 水銀のバイオボラタイゼーション＼cjkstart水 銀化合物を生物学的に処理するためには，まず処理 に用いる微生物が水銀化合物に対してどのように応 答するかについて明らかにすることが必要である. 水銀耐性菌 Pseudomonas K-62 は，菌体内に取り込 まれた水銀化合物を毒性の低い金属水銀 $\left(\mathrm{Hg}^{0}\right)$ に 代謝し, 生じた揮発性の $\mathrm{Hg}^{0}$ を菌体外へ気化・放 出することにより耐性を獲得している。この水銀還 元・気化活性を持つ微生物は, 水銀の除去・浄化に 利用できると考えられる.

1968 年に外村の研究グループはほかに先駆けて, Pseudomonas K-62 の持つ水銀還元活性を利用した 化学工業廃水中の水銀化合物の除去を試みた. ${ }^{41)}$ 本 水銀耐性菌を用いて化学工業廃水中の水銀化合物の 浄化試験を行ったところ，5-7 時間の間に 2.51 の 化学工業廃水から菌体湿重量 $1 \mathrm{~g}$ 当たりに約 $15 \mathrm{mg}$ の水銀化合物を除去できると報告している。この報 告は，微生物の水銀耐性機序（水銀のバイオボラ夕 イゼーション活性）をそのままの形で水銀浄化に利 用した最初の実験であった。 その後しばらくの間, これに関連する報告はなかった。しかし，1975 年 以後の微生物の水銀而性遺伝子の解明が，その後の 工場水銀廃水や水銀污染環境の処理・浄化技術の開 発に大きく貢献したことは事実である。例えば, Brunke らは merA 遺伝子を持つ種々の微生物から 調製した固定化細胞をカラムにつめ，これに $50 \mu \mathrm{g}$ $/ \mathrm{ml} \mathrm{Hg}^{2+}$ の廃液を流したところ，95\% 前後の無機 水銀イオンが金属水銀の形でカラム中に捕集された ことを報告した. ${ }^{42)}$ これ以後，無機水銀化合物の浄 化に微生物の持つ水銀還元・気化活性を利用する試 みは数多く報告された. ${ }^{43-48)}$ Wagner-Döblern の研 
究グループは，馴化した Pseudomonas 菌の持つ水 銀還元・気化活性と活性炭との併用により，苛性 ソーダ製造工場の廃水中の無機水銀を効率よく浄化 できることを報告した. ${ }^{45,47)}$

しかし，水銀耐性微生物の持つ merA 遺伝子に コードされる水銀還元活性を利用すると，最終的に 生じた金属水銀は揮発性が高いため，再び拡散して ほかの地域を污染するという問題がある。アマゾン 流域での水銀污染及びその全流域への污染拡大は, まさしくこの金属水銀に起因するものである. ${ }^{49-52)}$ そのため，水銀還元活性に基づく水銀浄化法が開放 系で使用された例は報告されていない.

3-2-2. 水銀のバイオアキュミュレーション法 水銀の還元・気化活性は多くの微生物に水銀耐性 を付与することが既に明らかにされている。，一方， 酵母や動物においては水銀化合物を無毒化するため の別の機構が存在している，それらの細胞内では， 金属イオンをキレートする働きのある生体物質が存 在する。一般に金属化合物は遊離イオンの形として 存在するよりもキレート体を形成する方がその毒性 は低いと考えられる。その一例としてメタロチオネ インが挙げられる，動物にカドミウムや水銀などの 金属化合物を投与すると，体内にメタロチオネイン が誘導合成される，その結果，体内に取り込まれた 金属がメタロチオネインによってキレートされるこ とにより解毒される. 1997 年, Chen と Wilson は メタロチオネイン生合成遺伝子と水銀輸送系遺伝子 を大腸菌内に同時に発現させると，菌体内に蓄積す る無機水銀量が対照菌の約 5 倍高くなることを見い 出した. ${ }^{53)}$ また， 2001 年，Baeらはファイトケラチ ン生合成遺伝子と水銀輸送系遺伝子を大腸菌内に形 質転換すると，対照菌に比べて約 6 倍高い無機水銀

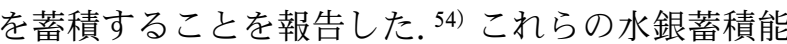
を付与した遺伝子組換え微生物は，環境中の水銀浄 化に利用できると考えられた。しかし，メタロチオ ネイン及びファイトケラチンの菌体内での発現量は 低いため，実用化には問題点があると思われる。

\section{4. ポリリン酸を利用した新規水銀浄化法の開発}

4-1. 廃水中の水銀浄化に用いる微生物の分子育

種筆者らは前項の問題点を克服し，実用化可能 な方法を目指して mer $A$ 遺伝子にコードされる水銀 還元活性を利用しない，新規水銀バイオアキュミュ レーションに基づく水銀浄化法の開発を試みた。
Pseudomonas K-62 の mer operonを利用して水 銀浄化を行う際に水銀化合物を気化させることな く，菌体内に水銀を回収させる場合には，まず $m e r A$ 及び $m e r G$ を欠失した mer operon の再構築 が必要であり, merT-merPにより菌体内に取り込 まれた水銀化合物をキレートし，その毒性を軽減で きる生体分子の生合成能を遺伝子組換えにより付与 する必要があると考えた。そこで，筆者らは生体内 で $\mathrm{Mg}, \mathrm{Ca}, \mathrm{Mn}$ などの生体必須二価金属をキレー トすることが知られているポリリン酸という分子に 着目した.

ポリリン酸は微生物や酵母などの生体内に普遍的 に存在する生体成分であり，生体内でポリリン酸キ ナーゼの作用により，ATP のエネルギーを利用 し，無機リン酸が数百個から千個ほど重合して作ら れる直鎖状ポリマーである. ${ }^{55-57)}$ ポリリン酸の生体 内での役割についてはまだ不明な点が多いが，生物 のエネルギー源，リン酸の貯蔵，二価必須金属のキ レート剤，遺伝子発現や転写の調節因子として機能 していることが報告されている. ${ }^{47-49)}$ 筆者らはま ず，ポリリン酸が水銀化合物のキレーターになり得 るかどうかを in vitro で調べた。その結果，一価の 有機水銀化合物はポリリン酸によりキレートされな いが，二価の無機水銀はそれによって効率よくキ レートされることが判明した. ${ }^{58,59)}$

そこで Pseudomonas K-62 の merR-o / p-merTmerP の下流に Klebsiella aerogenes 由来のポリリン 酸生合成を触媒するポリリン酸キナーゼ遺伝子 $p p k$ を組換えたプラスミド pMK27（merR-o/p-merT$m e r P-p p k)$ を作製し，大腸菌に形質転換した。 そ の結果， pMK27 を持つ大腸菌は, $p p k$ を持たない 対照菌に比べて無機水銀に対して高い耐性を示し た。これに加えて菌体内の水銀蓄積量は対照菌に比

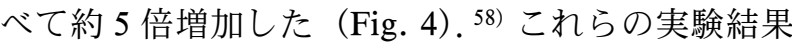
から，ポリリン酸が微生物に水銀而性及び水銀蓄積 能を付与することを初めて明らかにし，pMK27 は 環境中の無機水銀の浄化・回収に利用できると考え た.

一方，水銀化合物に関しては，環境に放出された 無機水銀の一部は自然環境に存在する微生物により 容易にメチル化され，結果としてメチル水銀の形で 環境に存在することが報告されている. ${ }^{60-62)}$ 自然環 境中で生成されたメチル水銀，あるいは農薬として 
使用されていたフェニル水銀などの有機水銀化合物 による土畩，食品污染及びそれによる人の健康影響 は大きな社会問題となっている.これらの有機水銀 化合物の浄化にもフォーカスを合わせなければなら ない。しかし，ポリリン酸は有機水銀をキレートす る活性を持たないため, pMK27 は有機水銀の浄 化・回収には適用できない欠点があった．無機水銀 のみならず有機水銀の浄化・回収をも同時に可能と

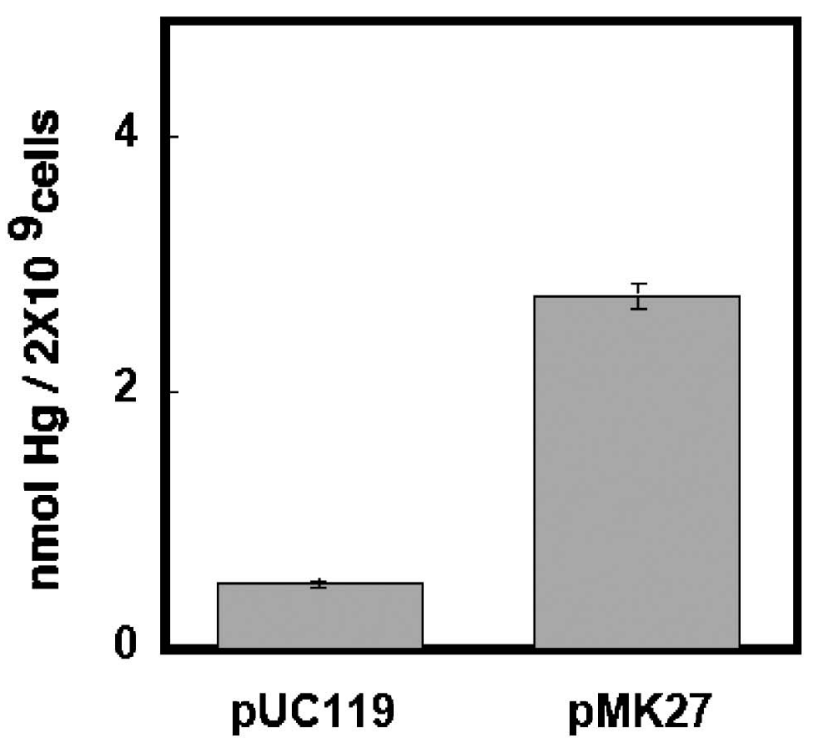

Fig. 4. Mercury Accumulation in E. coli with pMK27 The mercury accumulated in bacterial cells was determined after $24 \mathrm{~h}$ with $16 \mu \mathrm{M} \mathrm{Hg}{ }^{2+}$. The values are the means of triplicate experiments.
するために，筆者らは pMR26 上に存在する有機水 銀分解酵素遺伝子 merB を先に構築した $\mathrm{pMK} 27$ に 組換えたプラスミド pMKB18（merR-o/p-merTmerP-merB-ppk) を作製した。 pMKB18 を持つ大 腸菌のメチル水銀やフェニル水銀に対する耐性は, pMK27を持つ対照菌に比べて明らかに上昇した。 また, pMKB18 を持つ大腸菌の菌体内水銀蓄積量 は，ベクタープラスミドである pUC119 を持つ対 照菌に比べ，無機水銀の場合では約 10 倍，フェニ ル水銀の場合では約 3 倍上昇した. ${ }^{59)}$

以上の結果から， merT-merPにコードされる MerT-MerPにより菌体内に取り込まれた無機水銀 は，ppkにコードされるポリリン酸キナーゼによつ て生合成されたポリリン酸によりキレートされ，無 機水銀の毒性を軽減した形で菌体内に蓄積されると 考えられる。一方，菌体膜を通して取り込まれたメ チル水銀及び MerT-MerP により菌体内に取り込ま れたフェニル水銀は merB にコードされる有機水銀 分解酵素によって分解され，生じた無機水銀がポリ リン酸とキレートを形成し，ポリリン酸のキレート 体として菌体内に蓄積していると考えられる（Fig. 5)。このように遺伝子工学の手法を用いて微生物に 付与した水銀のバイオアキュミュレーション能力は 廃水における水銀の浄化回収に利用可能であること が示唆された。しかし，実用化に向けては浄化後の

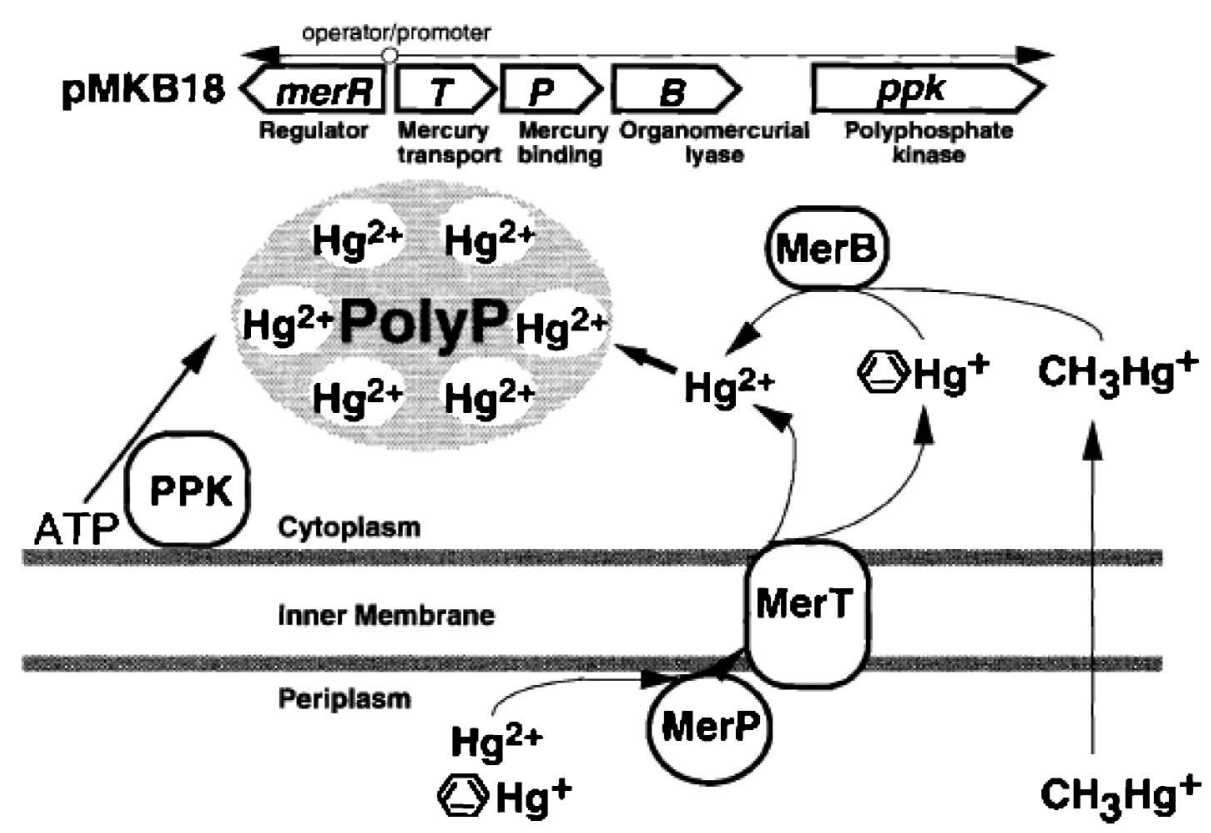

Fig. 5. A Schematic Model of the Mercury-removing System in E. coli with pMKB18 
微生物の回収法, また本浄化微生物の実環境への適 応性などの問題が残された。

そこで, 浄化後の微生物の回収を容易にする目的 で, 浄化微生物をアルギン酸ナトリウムを用いて直 径約 3-5 mm のビーズ状となるように固定化処理を 施した。本固定化細胞を用いて $\mathrm{Hg}^{2+}$ 及び $\mathrm{C}_{6} \mathrm{H}_{5}$ $\mathrm{Hg}^{+}$の浄化活性を調べた結果, $40 \mu \mathrm{M}$ までの $\mathrm{Hg}^{2+}$ 及び $20 \mu \mathrm{M}$ までの $\mathrm{C}_{6} \mathrm{H}_{5} \mathrm{Hg}^{+}$を含む廃水に対して, いずれも短時間内にほぼ完全に浄化された。 ${ }^{63)}$ ま た，これより高濃度の水銀廃水に対しても浄化可能 であり，その適用濃度範囲が広いことが判明した。 本固定化細胞により回収・蓄積された $\mathrm{Hg}^{2+}$ 及び $\mathrm{C}_{6} \mathrm{H}_{5} \mathrm{Hg}^{+}\left(\mathrm{Hg}^{2+}\right.$ の形として蓄積）は, 細胞乾燥重 量 $1 \mathrm{~g}$ 当たりそれぞれ約 890 及び $780 \mu \mathrm{mol}$ であっ た. ${ }^{63)} こ の$ 実験結果から算出した菌体内の水銀とポ リリン酸のモル比はおよそ 35 であり, ポリリン酸 はメタロチオネインの約 5 倍高い水銀キレート能を 持っている。.また，本固定化細胞は少なくとも 3 回，同じ濃度の水銀を含む廃水の浄化に再利用して も，その浄化活性がほぼ一定に保持されていた (Fig. 6).さらに，低栄養条件下やほかの重金属存 在下においても本固定化細胞の水銀浄化活性はほと んど影響を受けず一定であることが判明し，実験室 排水や工業廃水中の水銀浄化に栄養を付与すること なく利用できると確信している。このポリリン酸を 生合成する水銀浄化微生物は，水銀化合物のみなら ず，環境を污染して問題となっている $\mathrm{Cd}^{2+}$ などに 対しても耐性を示すことからこれらの重金属の浄

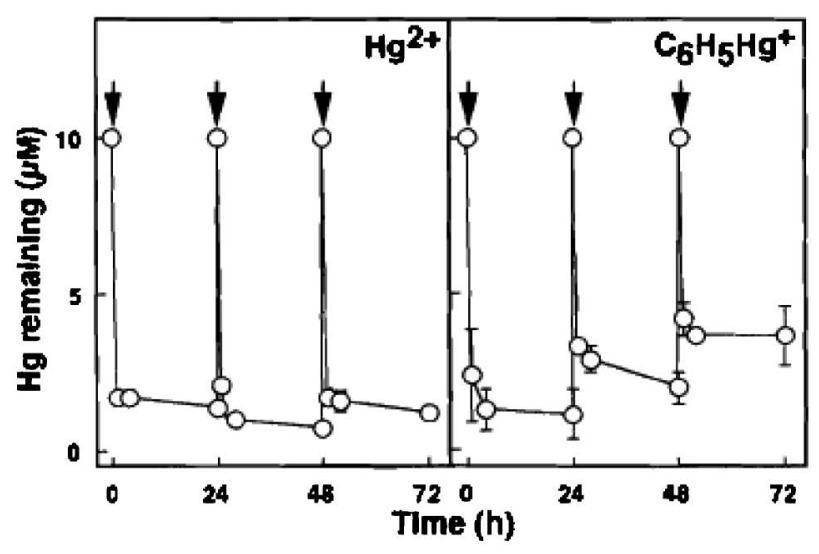

Fig. 6. Removal of Mercurials by Immobilized E. coli with pMKB18

After incubation with $10 \mu \mathrm{M}$ mercurial for indicated time, mercury remaining in the bead-free medium was determined. The values are means of triplicate experiments.
化・回収に利用可能であることが示唆された. ${ }^{63)}$

以上の結果から，筆者らが構築した新しい生物学 的水銀浄化法は，従来の $\operatorname{mer} A$ を用いたバイオボラ タイゼーション法と異なり, 少なくとも浄化後の水 銀が再び環境に拡散して環境を再污染する懸念が少 なく，また，固定化細胞を利用するため用いる微生 物による生態系の污染という懸念も少なく，開放系 中の水銀浄化に利用し易いと考えられる。ポリリン 酸は微生物に存在する生体成分の 1 つであり，最適 条件下では菌体湿重量の $40 \%$ まで発現，蓄積する

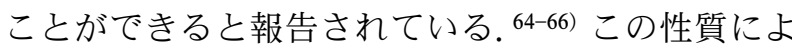
り，本浄化微生物がポリリン酸の基質である無機リ ンに起因する水の富栄養化の解消にも大きく寄与す る可能性を秘めており, 極めて斬新な生物学的水銀 浄化法であると言える。しかし，本浄化系は廃水中 の水銀化合物の浄化を目指して構築したものであ り，土壤水銀のバイオレメディエーションを行う場 合, 浄化微生物の生育制御やバイオマスの回収が極 めて困難であるなど，污染土袞中の水銀浄化には利 用し難い技術的な限界があった。

4-2. 土壤中の水銀浄化に用いる植物の分子育種 水銀による污染土壤の浄化には多くの問題点があ り，それを回避する最も有効な手段は水銀回収・蓄 積能を付加させたトランスジェニック植物の創生だ と思われる。

これまで水銀污染土袞の浄化修復には浚渫，埋め 立て，高温加熱処理及び土壇洗浄などの物理化学的 処置方法が汎用されている。 しかし，これらの施策 には莫大な費用を必要とし，また，熱処理や化学薬 品処理により土壤の本来の性質を損なうことに加 え, ダイオキシンのような非意図的に有害な化学物 質が産生される可能性があるため広範囲に及ぶ敷地 や農業利用地への適用が困難である。そこで近年, 水銀などの化学污染物質の污染浄化に植物を利用す るファイトレメディエーション技術が注目されてい る. 現在，水銀化合物のファイトレメディエーショ ンに適するトランスジェニック植物の創生が次々試 みられている. ${ }^{67-73)}$ その多くは土袞中の水銀化合物 を根から吸収し植物体を経て，金属水銀として葉か ら大気中へ拡散させるものが主軸となっている。し かし, 大気中に放出される金属水銀は再びほかの地 域を污染する懸念があるため実用化には至っていな い.この問題点を解決するために水銀高蓄積植物の 
分子育種が必要であると考えた。そこで筆者らは, 水銀回収・蓄積能を付加させたトランスジェニック 植物を創出すれば，ファイトレメディエーションの 技術を用いて水銀污染土畩の浄化及び本トランスジ エニック植物体内からの水銀回収・リサイクルの両 目的が同時に達成できると考えた。また，水銀污染 土壤の浄化は, 将来的に実用化されてこそその研究 に価値があると信じている。世界各地の污染地域を 想定した場合，栄養や水が不足した土壌でも容易に 育ち，また，バイオマスが大きく高い浄化効率が期 待できることが要求される。ささらに考慮しなくては いけないこととして，遺伝子組換え植物を使用する ことの環境への影響がある。そのため，二コチンを 多く含有し，鳥などによる葉の捕食が少ないために 食物連鎖の影響をほとんど受けることがないと考え られるタバコを植物体として選定した。

最初に，遺伝子工学技術を用いて多量かつ多数の 二価金属をキレートする活性を持つポリリン酸の生 合成酵素遺伝子 $(p p k)$ を組換えた水銀高蓄積夕バ コの作出を試みた。細菌由来の $p p k$ 遺伝子が菌体 内及び植物細胞内に翻訳され易いように $p p k$ 遺伝 子の $5^{\prime}$ 末端に SD 配列（AGAAGG）及び PT 配列 （AACCACA）を付加した $p p k$ 遺伝子断片を分子設 計した。これらの配列を有する $p p k$ 遺伝子断片を PCR 法により増幅した後，バイナリーベクター （pHM6）に組換えたプラスミド（pPKT116）を構 築した。次に，植物に対して感染能を有する Agrobacterium tumefaciens を介して Nicotiana tabacum cv. Samsun NN（タバコ）のゲノムに $p p k$ 遺伝子断 片を導入した。得られた遺伝子組換えタバコの葉中 に $p p k$ 遺伝子の存在及び本遺伝子が植物体内で転 写・翻訳されてポリリン酸キナーゼ (PPK) タン パク質として発現していることが PCR 法及び抗 PPK 抗体を用いた Western-Blotting 法により確認 された. ${ }^{73)} さ ら に ， 4^{\prime}, 6^{\prime}$-diamidino-2-phenylindole （DAPI）染色法を用いてポリリン酸を検出した結 果, $p p k$ 遺伝子組換えタバコの葉及び根でポリリン 酸顆粒が多数検出された。これらのことから, 組換 えた $p p k$ 遺伝子は夕バコ細胞中でポリリン酸を生 合成し得る活性型の PPK として翻訳されているも のと考えられる. ${ }^{73,74)}$

水銀の浄化に用いる植物は環境中の水銀化合物に 対して耐性を示し，本来の植物と同様，成長するこ
とが必須条件である。そこで， $p p k$ 遺伝子組換え夕 バコの水銀化合物に対する応答を調べた結果，本遺 伝子組換え夕バコは，野生株の夕バコに比べて無機 水銀に対して強い耐性を示した. $\left.{ }^{73}, 74\right)$ このことから, $p p k$ 遺伝子組換えタバコに取り込まれた無機水銀は PPK により生合成されたポリリン酸によって，毒 性の低いポリリン酸キレート体となっていると考え られる。次に，本遺伝子組換え夕バコの水銀浄化・ 回収活性を調べた結果，水銀污染モデル土壌中で野 性株に比べて高い水銀浄化・回収蓄積能を示すこと が判明した (Fig. 7).

これは，植物内に取り込まれた無機水銀が毒性の 低い水銀ーポリリン酸キレート体として植物細胞内 に蓄積しているためと考えられる．以上の結果から， $p p k$ 遺伝子が夕バコに高い水銀耐性及び水銀蓄積性 を付与したことが本研究により初めて明らかとな り，本遺伝子組換えタバコは水銀污染土壌の浄化に 利用し得ると考えた。

植物を利用した環境浄化のメリットとして，太陽 エネルギーを利用するので従来の物理化学的処置方 法に比べて低コストで浄化できる，また，原位置処 理のため二次的な污染リスクが少ないこと，さらに 生態系に大きな負荷を与えることなく環境修復でき ることなどが挙げられる。一方，デメリットとして 土㙥燃焼法や溶媒抽出法など，従来のニーズ即応型 の環境浄化法に比べると，浄化完了までに長い時間

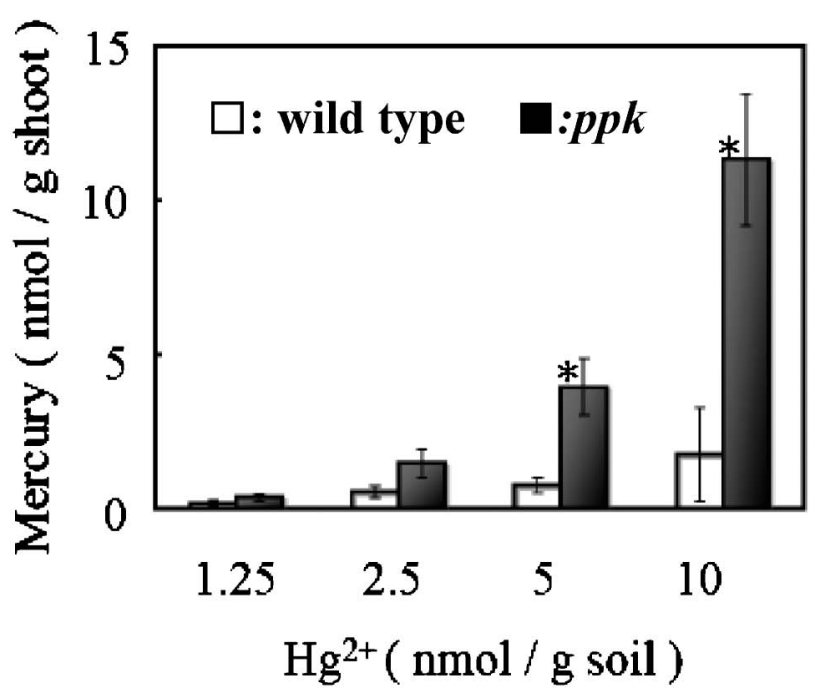

Fig. 7. Accumulation of Mercury in Transgenic Tobacco from Soil

Data are expressed as the mean \pm S.E.M. of three determinations from three independent experiments. ${ }^{*} p<0.05$ vs. wild type. 
を要することや污染物質を完全に取り除くことがで きないことなどが挙げられる，なぜなら，植物は生 育には不要な元素や有害な物質の吸収を抑制する防

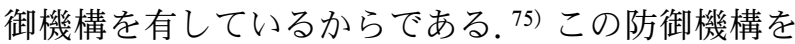
打破するため浄化対象物質の取り込み系の付与は 1 つの解決方法であると考えた。

そこで筆者らは，水銀高蓄積夕バコ（ $p p k$ 遺伝子 組換えタバコ）への水銀取り込み量を向上させる目 的で水銀而性菌 Pseudomonas K-62 由来の水銀輸送 遺伝子 $m e r T^{24)}$ を $p p k$ 遺伝子組換えタバコへの遺 伝子導入を試みた。まず, 夕バコ体内で $\operatorname{mer} T$ 遺伝 子から転写・翻訳された MerT タンパク質の検出を 容易にするために， merT 遺伝子の下流に， myctag 遺伝子を付加し, さらに $\operatorname{mer} T$ 遺伝子が菌体内 及び植物細胞内において転写・翻訳され易いように, $m e r T$ 遺伝子の上流に $\mathrm{SD}$ 配列及び PT 配列を付加 した $\operatorname{mer} T$ 遺伝子断片を分子設計した。これらの配 列を有する $\operatorname{mer} T$ 遺伝子断片を先の場合と同様，バ イナリーベクターに組換えた後 A. tumefaciens を 介して $p p k$ 遺伝子組換えたタバコのゲノムに導入 した。得られた $p p k / m e r T$-遺伝子組換えタバコの 葉において $\operatorname{mer} T$ 遺伝子の存在またその遺伝子が MerT タンパク質に転写・翻訳されたことが PCR 法及び抗 c-Myc 抗体を用いた Western-Blotting 法 により確認された. ${ }^{76)}$ 以上の実験事実から，Pseudomonas $\mathrm{K}-62$ 由来の水銀輸送遺伝子 $\operatorname{mer} T$ を付加 した遺伝子組換えタバコの分子育種に成功したもの と考えられる。次に，得られた $p p k / m e r T$ 遺伝子 組換えタバコより収穫した種から栽培した若苗を用 いて水銀の取り込み活性及び蓄積性を調べた。その 結果，水銀輸送体を持たない $p p k$ 遺伝子のみを組 換えたタバコに比べて, $p p k / m e r T$ 遺伝子組換え夕 バコは水銀曝露開始直後から積極的に水銀を取り込 み， 24 時間後には $p p k$ 遺伝子のみを組換えた夕バ コのおよそ 2 倍高い水銀取り込み量を示した（Fig. 8). ${ }^{76)}$

ここで創生した $p p k / m e r T$ 遺伝子組換えタバコ は MerT の水銀取り込み活性により水銀浄化能が促 進していることから，本組換え株を用いることによ り浄化完了時間が大きく短縮可能であることが示唆 された

さらに, $p p k / m e r T$ 遺伝子組換えタバコは $p p k$ 遺 伝子組換えタバコに比へ，比較的低濃度の水銀を含

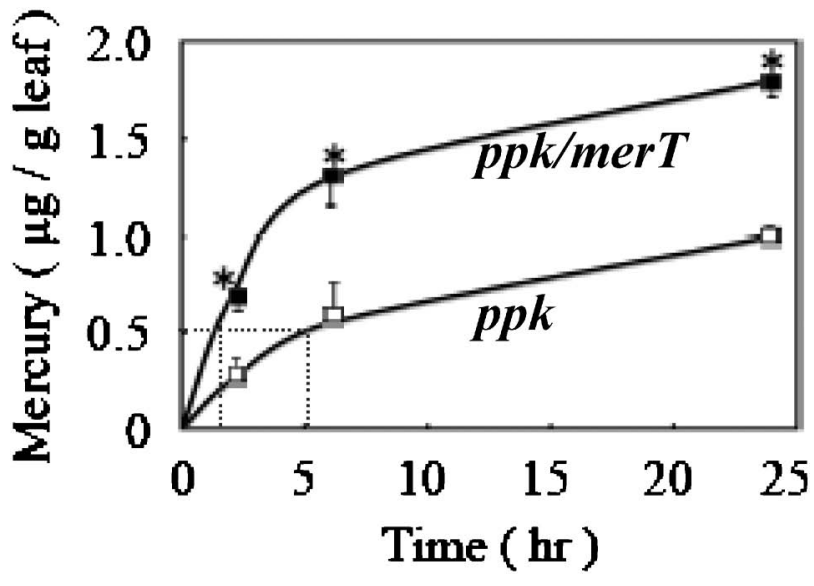

Fig. 8. Mercury Uptake in $p p k / m e r T$-transgenic Tobacco Data are expressed as the mean \pm S.E.M. of three determinations from three independent experiments. ${ }^{*} p<0.05 v s$. ppk.

むモデル土壤から多量の水銀を回収・蓄積している

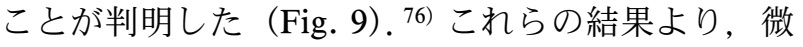
量水銀の浄化に不適であるというファイトレメディ エーションの欠点の 1 つが大きく改善し得ることが 初めて明らかとなり，植物を用いた重金属の浄化技 術の革新に大きく貢献したものと考えられる.

しかし, 本 $p p k / m e r T$ 遺伝子組換えタバコは無 機水銀の回収・蓄積には有効であるが，メチル水銀 等の有機水銀化合物の浄化に利用できないという欠 点がある。その理由はポリリン酸が一価の有機水銀 化合物をキレートできないためである. ${ }^{58,59)}$ 環境中 に排出された無機水銀が微生物等によりメチル化さ れ，神経毒性の強いメチル水銀に変換される機構が 存在することが知られている。 ${ }^{8-10)}$ 環境中で生成さ れたメチル水銀や人為的に排出されたメチル水銀を 始めとする有機水銀による人への健康影響が懸念さ れており，無機水銀の浄化だけではなくメチル水銀 を始めとする有機水銀の浄化も必要とされている. そこで筆者らは, $p p k / m e r T$ 遺伝子組換えタバコに 有機水銀分解酵素遺伝子 $\operatorname{mer} B$ を導入し，土壤中の 無機水銀の夕ならずメチル水銀の浄化にも利用でき る水銀浄化トランスジェニック植物の創生を試みた.

水銀輸送体を持つ水銀高蓄積夕バコ（ppk/merT 遺伝子組換えタバコ）への merB 遺伝子の導入とし て，まずタバコ体内で $m e r B$ 遺伝子から転写・翻訳 された MerB タンパク質の検出を容易にするため, merB 遺伝子の下流に flag-tag 遺伝子を付加し，さ らに $m e r B$ 遺伝子が菌体内及び植物細胞において転 


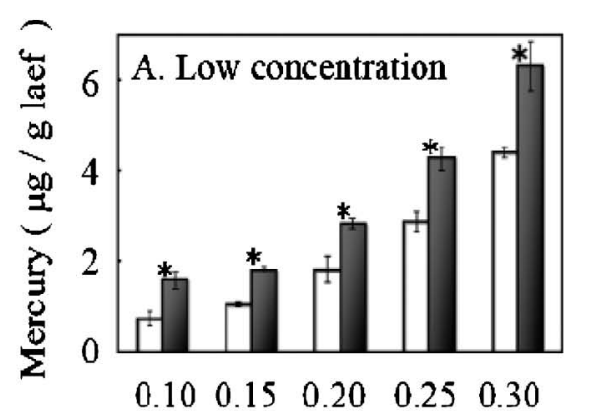

$\mathrm{Hg}^{2+}(\mu \mathrm{M})$

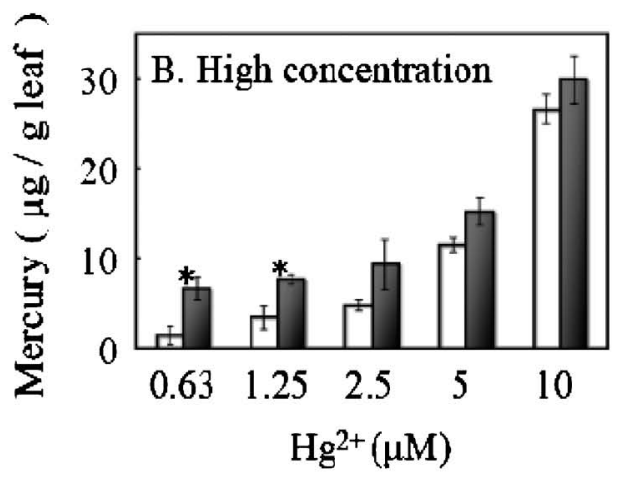

$\mathrm{Hg}^{2+}(\mu \mathrm{M})$

$\square: p p k, \quad \square: p p k / m e r T$

Fig. 9. Mercury Accumulation in Transgenic Tobacco

Data are expressed as the mean \pm S.E.M. of three determinations from three independent experiments. ${ }^{*} p<0.05 v s$. ppk.

写・翻訳され易いように, merB 遺伝子の上流に $\mathrm{SD}$ 配列及び PT 配列を付加した $\operatorname{mer} B$ 遺伝子断片 を分子設計した。これらの配列を有する merB 遺伝 子断片をPCR 法で増幅した後, バイナリーベク ターに組換えた。次に, A. tumefaciens の感染力を 介して $\operatorname{merB}$ 遺伝子断片を $p p k / m e r T$ 遺伝子組換え タバコのゲノムに導入した。得られた $p p k / m e r T /$ merB 遺伝子組換えタバコの葉において merB 遺伝 子が MerB タンパク質に転写・翻訳されたことが抗 Flag 抗体を用いた Western-Blotting 法により確認 された。 さらに，抗 PPK 抗体及び抗 Myc 抗体を用 いた Western-Blotting により PPK 及び MerT タン パク質がいずれもタバコの葉の抽出液中に検出され たことから,$p p k$ 遺伝子及び $m e r T$ 遺伝子はともに それぞれ転写・翻訳されていることが確認され た. ${ }^{77)}$ 水銀のない状態では $p p k / m e r T / m e r B$ 遺伝子 組換え夕バコの成長は野性株及び $p p k / m e r T$ 遺伝 子組換え夕バコとの差は認められず， merB 遺伝子 の導入は夕バコの成長の妨げにならないことが明ら かとなった。 メチル水銀濃度の増加に伴い， 3 者の 成長率がともに減少しているが $p p k / m e r T / m e r B$ 遺 伝子組換え夕バコの成長率はほかの 2 者に比べ明ら かに大きく, $\operatorname{mer} B$ 遺伝子の導入によりメチル水銀 に対する耐性能が大きく増強されていることが明ら

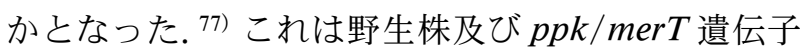
組換え株においては，吸収されたメチル水銀が細胞 内で毒性を発現したためと考えられる。一方，細胞 内でメチル水銀分解酵素 MerB を発現し得る $p p k$ / merT/merB 遺伝子組換え株では, 野生株及び $p p k /$ $m e r T$ 遺伝子組換え株に比べて耐性を示したことか
ら，MerB が細胞内で活性を示し，メチル水銀を無 機水銀に分解し，その後生じた無機水銀がポリリン 酸によりキレートされ，毒性の低い無機水銀-ポリ リン酸キレート体になったものと考えられる.

次に, $p p k / m e r T / m e r B$ 遺伝子組換え株のメチル 水銀浄化活性を調べた結果，本遺伝子組換え株には 野生株及び $p p k / m e r T$ 遺伝子組換え株に比へ，有 意に高い水銀蓄積量を示した。この結果は，本遺伝 子組換え株は取込まれたメチル水銀が有機水銀分解 酵素（MerB）により無機水銀に分解された後，無 機水銀ーポリリン酸キレート体となってタバコ細胞 内に蓄積していることを示唆している，なお，培地 中に残存するメチル水銀量を測定したところ，野生 株及び ppk/merT 遺伝子組換え株ではいずれも培 地中に多量のメチル水銀が残存していたのに対し， $p p k / m e r T / m e r B$ 遺伝子組換え株のメチル水銀残存 量は大きく減少していた。このことから, $p p k$ 遺伝 子及び $m e r B$ 遺伝子が遺伝子組換え夕バコ中に効果 的に働いていることが確認できた（Fig. 10). ${ }^{77)}$

以上の結果から, ppk, merT 及び merB の 3 遺伝 子を同時に発現し，土袞中の無機水銀のみならず, メチル水銀を始めとする有機水銀の浄化・回収に利 用できる新規水銀高蓄積 $p p k / m e r T / m e r B$ 遺伝子組 換えタバコの分子育種に成功したと確信している.

現在，ファイトレメディエーションを用いた水銀 污染土壌の浄化・修復法の開発研究を系統的かつ持 続的に行っているのは主として，米国ジョージア大 学とわれわれの 2 研究グループと思われる. ジョー ジア大学グループは merA 及び merB 遺伝子を植物 に導入しており，取り込まれた水銀は植物体内に蓄 


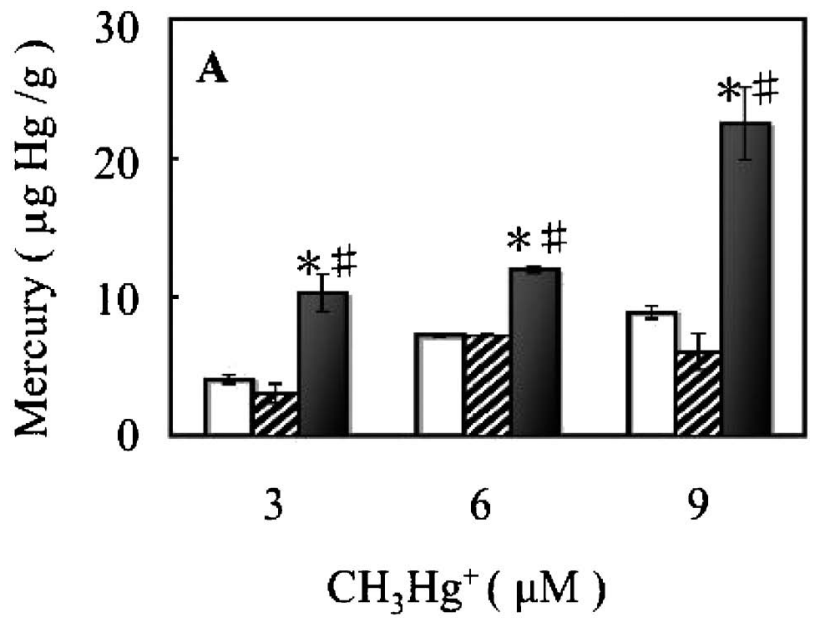

wild-type $(\square), p p k / m e r T$-transgenic $(\mathbb{N})$ ppk/merT/merB-transgenic ( $\square$ )

Fig. 10. Mercury Accumulation from $\mathrm{CH}_{3} \mathrm{Hg}^{+}$-containing Medium

Data are expressed as the mean \pm S.E.M. of three determinations from three independent experiments. ${ }^{*} p<0.05 v s$. wild type. ${ }^{*} p<0.05 v s . p p k /$ merT.

積することなく，大気中に放出される．一方，われ われの方法では夕バコ中に蓄積されるため, 回収す ることが可能であり，浄化後の水銀による二次污染 の心配がなく，加えて，回収により資源のリサイク ルが可能な，より優れた方法だと考える．なお，植 物体中に蓄積している水銀ーポリリン酸キレート体 はポリリン酸抽出法により回収が可能であることを 確認しており，今後はさらにその回収法の効率化を 図る予定である.

微生物由来の遺伝子を植物に導入し，発現させる ことは技術的に困難な面もあるが，目的遺伝子の分 子設計を始めとする遺伝子組換えの各ステップを着 実に行った結果，少なくとも本研究の目標である 「実施可能な無機・有機水銀土壤の浄化に適用でき る新規水銀浄化トランスジェニック植物の創出」を ほぼ完成することができたと考える，本研究の成果 は実用化の一歩手前にきており，小規模であっても フィールドワークを行うことが重要である.

\section{5. おわりに}

水銀化合物によって污染された環境を浄化するた めにこれまで用いられてきた方法は主として物理化 学的方法である。しかしながら，ここで述べたよう に，環境に生棲している水銀耐性菌の多くは自分自 身の周りにある水銀化合物を無毒化し，気化・除去
する能力を持っている. この水銀気化除去能力, 又 は，遺伝子工学の手法を用いて微生物に付与した水 銀バイオアキュミュレーション能力を利用して廃水 また污染土袞環境から水銀化合物を浄化する新しい 環境技術を開発することができるようになった。

筆者らがここで提案した水銀輸送系，有機水銀分 解系及びポリリン酸生合成系と共役した新しい生物 学的水銀浄化法は，従来の水銀還元気化法とは異な り，少なくとも処理後の水銀が環境を再污染する懸 念が少なく，開放系の浄化にも利用し易いものであ る。また，ppk 遺伝子を利用することにより無機り ン化合物に起因する富栄養化の解消にも役立つ可能 性を持ち，環境に優しい生物学的水銀浄化法である と言えるであろう。

日本国内においては水銀などの重金属污染に起因 する健康被害とその罹患率は時を経て減少している が，目を世界に向けるとこれからの健康リスクが問 題となる土袞污染は多く存在する。その多くは開発 途上国であり，かつての日本の状況が再現される可 能性も高く，わが国の失敗を繰り返さないようにす ることが大切である．本研究は，実用化すること で，世界の環境，特に経済的に恵まれていない発展 途上国の人々の生活と福祉に大きく貢献できる内容 であり，過去に水俣や新潟での苦い経験を持ち，ま た経済的にはまだゆとりのある日本がリーダーシッ プを取り，実現化の推進をしていくに值することと 思う。

謝辞＼cjkstart筆を置くにあたり, 本研究の開始から完 了に至るまで御想篤なる御指導並びに御鞭撻を賜り ました恩師 井村伸正教授 (元北里大学薬学部) に 深甚なる感謝の意を表します。本研究テーマに真摰 に協力，かつ貢献して頂いた教室員 清野正子准教 授 (現北里大学薬学部), 長田 武講師 (現摂南大 学理工学部), 研究員 大村朋子博士並びに研究室 に在籍された大学院生，卒業研究生の方々に心から お礼を申し上げます。本研究を進めるにあたり plasmid pKP02.1 を形質転換した大腸菌 JM109を 御恵贈頂きました東北学院大学工学部環境工学研究 分野 遠藤銀朗教授に，また，バイナリーベクター pHM-6 及び Agrobacterium tumefaciens LBA4404 を御恵贈頂きました京都大学生存圈研究所森林圈遺 伝子統御分野 矢崎一史教授に，また，タンパク質 
に関する専門的な御助言と Western-Blotting に用い る抗 PPK 抗体の抗原となる PPK ペプチドを合成 頂きました摂南大学薬学部臨床分析化学研究室 秋 澤俊史教授に深謝致します。最後に，研究室の運営 に御尽力を賜りました藤森廣幸教授に本心より感謝 し，お礼を申し上げます。

\section{REFERENCES}

1) Kitamura S., Kondou M., Takizawa Y., Fujii M., Fujiki S., “Mercury,” Kodansha, Tokyo, 1976.

2) Tsubaki T., Irukayama K., “Minamata Disease-Methylmercury Poisoning in Minamata and Niigata, Japan," Elsevier Scientific Publishing Co., Amsterdam, 1977.

3) Nishimura H., Okamoto T., "Minamatabyou no Kagaku," Nippon Hyoronsha Co., Ltd., Tokyo, 2001.

4) Tomizawa T., Shoku no Kagaku, 18, 39-45, (1974)

5) Matsuyama A., Liya Q., Yasutake A., Yamaguchi M., Aramaki R., Xiaojie L., Pin J., Mei L., Yumin A., Yasuda Y., Bull. Environ. Contam. Toxiol., 73, 846-852 (2004).

6) Pan-Hou H. S., Nishimoto M., Imura N., Arch. Microbiol., 130, 93-95 (1981).

7) Pan-Hou H. S., Imura N., Arch. Microbiol., 129, 49-52 (1981).

8) Pan-Hou H. S., Imura N., Arch. Microbiol., 131, 176-177 (1982).

9) Pan-Hou H. S., Imura N., Bull. Environ. Contam. Toxicol., 29, 290-297 (1982).

10) Trevors J. T., J. Bacteriol., 26, 499-504 (1986).

11) Osborn A. M., Bruce K. D., Strike P., Ritchie D. A., FEMS Microbiol. Rev., 19, 239-262 (1997).

12) Silver S., Walderhaug M., Microbiol. Rev., 56, 195-228 (1992).

13) Silver S., Phung L. T., Annu. Rev. Microbiol., 50, 753-789 (1996).

14) Summers A. O., Annu. Rev. Microbiol., 40, 607-634 (1986).

15) Tonomura K., Maeda K., Futai F., Nakagami T., Yamada M., Nature, 217, 644-646 (1968).

16) Tonomura K., Nakagami T., Futai F., Maeda K., J. Ferment. Technol., 46, 506-512 (1968).

17) Furukawa K., Suzuki T., Tonomura K.,
Agric. Biol. Chem., 33, 128-130 (1969).

18) Tonomura K., Kanzaki F., Biochim. Biophys. Acta, 184, 227-229 (1969).

19) Furukawa K., Tonomura K., Agric. Biol. Chem., 35, 604-610 (1971).

20) Furukawa K., Tonomura K., Agric. Biol. Chem., 36, 217-226 (1972).

21） Tezuka T., Tonomura K., J. Biochem., 80, 7987 (1976).

22) Tezuka T., Tonomura K., J. Biochem., 135, 138-143 (1978)

23) Griffin H. G., Foster T. J., Silver S., Misra T. K., Proc. Natl. Acad. Sci. USA, 84, 31123116 (1987).

24) Kiyono M., Omura T., Inuzuka H., Fujimori H., Pan-Hou H., Gene, 189, 151-157 (1997).

25) Kiyono M., Pan-Hou H., Biol. Pharm. Bull., 22, 910-914 (1999).

26) Huang C. C., Narita M., Yamagata T., Endo G., Gene, 239, 361-366 (1999).

27) Liebert C. A., Hall R. M., Summers A. O., Microbiol. Mol. Biol. Rev., 63, 507-522 (1999)

28) Barkay T., Miller S. M., Summers A. O., FEMS Microbiol. Rev., 27, 355-384 (2003).

29) Kiyono M., Sone Y., Nakamura R., Pan-Hou H., Sakabe K., FEBS Lett., 583, 1127-1131 (2009)

30) Kusano T., Ji G., Inoue C., Silver S., J. Bacteriol., 172, 2688-2692 (1990).

31) Hamlett N. V., Landale E. C., Davis B. H., Sommers A. O., J. Bacteriol., 174, 6377-6385 (1992)

32) Inoue C., Kusano T., Silver S., Biosci. Biotechnol. Biochem., 60, 1289-1292 (1996).

33) Reniero D., Mozzon E., Galli E., Barbieri P., Gene, 208, 37-42 (1998).

34) Wilson J. R., Leang C., Morby A. P., Hobman J. L., Brown N. L., FEBS Lett., 472, 78$82(2000)$.

35) Kiyono M., Pan-Hou H., J. Bacteriol., 181, 726-730 (1999).

36) Kiyono M., Omura T., Fujimori H., Pan-Hou H., Arch. Microbiol., 163, 242-247 (1995).

37) Kiyono M., Omura T., Fujimori H., Pan-Hou H., FEMS Microbiol. Lett., 128, 301-306 (1995)

38) Uno Y., Kiyono M., Tezuka T., Pan-Hou H., Biol. Pharm. Bull., 20, 107-109 (1997). 
39) Kuyucak N., Volesky B., Biotechnol. Lett., 10, 137-142 (1988).

40) Gardea-Torresdey J. L., Becker-Hapak M. K., Hosea J. M., Darnall D. W., Environ. Sci. Technol., 24, 1372-1378 (1990).

41) Suzuki T., Furukawa K., Tonomura K., J. Ferment. Technol., 46, 1048-1055 (1968).

42) Brunke M., Deckwer W. P., Frischmuth A., Horn J. M., Lunsdorf M., Rhode M., Rohricht M., Timmis K. N., Weppen P., FEMS Microbiol. Rev., 11, 145-152 (1993).

43) Saouter E., Turner R., Barkay T., Ann. NY Acad. Sci., 721, 423-427 (1994).

44) von Canstein H., Li Y., Timmis K. N., Deckwer W. D., Wagner-Döbler I., Appl. Environ. Microbiol., 65, 5279-5284 (1999).

45) Wagner-Döbler I., von Canstein H., Li Y., Timmis K. N., Deckwer W. D., Environ. Sci. Technol., 34, 4628-4634 (2000).

46) Okino S., Iwasaki K., Yagi O., Tanaka H., J. Environ. Biotechnol., 1, 41-47 (2001).

47) von Canstein H., Li Y., Wagner-Döbler I., Biotechnol. Bioeng., 74, 212-219 (2001).

48) Narita N., Yamagata T., Ishii H., Huang C. C., Endo G., Appl. Microbiol. Biotechnol., 59, 86-90 (2002).

49) Martinelli B. L. A., Ferreira J. R., Forsberg B. R., Victoria R. L., Ambio, 17, 252-254 (1988).

50) Pfeiffer W. C., Lacerda L. D., Environ. Technol. Lett., 9, 325-330 (1988).

51) Lacerda L. D., Pfeiffer W. C., Quim. Nova, 55, 283-294 (1992).

52) Nriagu J. O., Pfeiffer W. C., Malm O., Souza C. M. M., Mierle G., Nature, 356, 389 (1992).

53) Chen S., Wilson D. B., Appl. Environ. Microbiol., 63, 2442-2445 (1997).

54) Bae W., Mehra R. K., Mulchandani A., Chen W., Appl. Environ. Microbiol., 67, 5335-5338 (2001).

55) Kulaev I. S., “The Biochemistry of Inorganic Polyphosphates,' John Wiley \& Sons, Inc., New York, 1979.

56) Pisoni R. L., Lindley E. R., J. Biol. Chem., 267, 3626-3631 (1992).

57) Kornberg A., J. Bacteriol., 177, 491-496 (1995).

58) Pan-Hou H., Kiyono M., Kawase T., Omura T., Endo G., Biol. Pharm. Bull., 24, 1423-
1426 (2001).

59) Pan-Hou H., Kiyono M., Omura H., Omura T., Endo G., FEMS Microbiol. Lett., 207, 159164 (2002)

60) Jensen S., Jernelöv A., Nature, 223, 753-754 (1969).

61) Spangler W. J., Spigarelli J. L., Rose J. M., Miller H. M., Science, 180, 192-193 (1973).

62) Yamada M., Tonomura K., J. Ferment. Technol., 50, 159-166 (1972).

63) Kiyono M., Omura H., Omura T., Murata S., Pan-Hou H., Appl. Microbiol. Biotechnol., 62, 274-278 (2003).

64) Archibald F. S., Fridovich I., Arch. Biochem. Biophys., 215, 589-596 (1982).

65) Pisoni R. L., Lindley E. R., J. Biol. Chem., 267, 3626-3631 (1992).

66) Dunn T., Gable K., Beeler T., J. Biol. Chem., 269, 7273-7278 (1994).

67) Rugh C. L., Wilde H. D., Stack N. M., Thompson D. M., Summers A. O., Meagher R. B., Proc. Natl. Acad. Sci. USA, 93, 3182-3187 (1996).

68) Rugh C. L., Senecoff J. F., Meagher R. B., Merkle S., Nat. Biotechnol., 16, 925-928 (1998)

69) Bizily S. P., Pugh C. L., Summers A. O., Meagher R. B., Proc. Natl. Acad. Sci. USA, 96, 6808-6813 (1999).

70) Bizily S. P., Pugh C. L., Meagher R. B., Nat. Biotechnol., 18, 213-217 (2000).

71) Bizily S. P., Kim T., Kandasamy M. K., Meagher R. B., Plant Physiol., 131, 463-471 (2003).

72) Ruiz O. N., Hussein H. S., Terry N., Daniell H., Plant Physiol., 132, 1344-1352 (2003).

73) Nagata T., Kiyono M., Pan-Hou H., Appl. Microbiol. Biotechnol., 72, 777-782 (2006).

74) Nagata T., Ishikawa C., Kiyono M., Pan-Hou H., Biol. Pharm. Bull., 29, 2350-2353 (2006).

75) Taiz L., Zeiger E., "Plant Physiology,'” 3rd ed., Sinauer Associates, Inc., Sunderland, 2002.

76) Nagata T., Nakamura A., Akizawa T., PanHou H., Biol. Pharm. Bull., 32, 1491-1495 (2009).

77) Nagata T., Morita H., Akizawa T., Pan-Hou H., Appl. Microbiol. Biotechnol., 87, 781-786 (2010). 